\title{
Clinical Feature and Survival Outcomes of Lung Cancer with ALK Mutation Positive and Treated with Crizotinib, Single Centre Experience
}

\section{ALK Mutasyonu Pozitif ve Crizotinib ile Tedavi Edilmiş Akciğer Kanserli Olguların Klinik Özellikleri ve Sağkalım Sonuçları; Tek Merkez Deneyimi}

\author{
Burak Bilgin, Şebnem Yücel \\ Ankara Atatürk Göğüs Hastalıkları ve Göğüs Cerrahisi Eğitim ve Araştırma Hastanesi, Tıbbi Onkoloji, Ankara
}

Dergiye Ulaşma Tarihi:12.02.2019 Dergiye Kabul Tarihi:30.04.2019 Doi: 10.5505/aot.2019.52523

\section{ÖZET}

GIRIŞ ve AMAÇ: ALK pozitif akciğer kanseri tüm akciğer kanserli olguları küçük bir bölümünü oluşturur. Özellikle son yıllarda ALK mutasyonu pozitif olgularda hedefe yönelik tedavilerin geliştirilmesi ile sağkalım sonuçlarında belirgin iyileşmeler görülmektedir. Bu çalışmada da ALK mutasyonu pozitif ve herhangi bir basamakta crizotinib uygulanmış akciğer kanserli olgularda klinik özelliklerin ve sağkalım sonuçlarının belirlenmesi amaçlanmıştır.

YÖNTEM ve GEREÇLER: Ankara Atatürk Göğüs Hastalıkları ve Göğüs Cerrahisi Eğitim ve Araştırma Hastanesi, Tıbbi onkoloji polikliniğine 2014 - 2018 yılları arasında başvurmuş hastalar çalışmaya dahil edilmiş ve verileri retrospektif olarak toplanmıştır.

BULGULAR: Toplam 48 hasta çalışmaya dahil edilmiş olup hastaların büyük çoğunluğu metastatik $(\% 86,7)$ ve sigara içmemiş $(\% 68,8)$ hastalardan oluşmaktaydı. Birinci basamakta crizotinib kullanan hastalarda crizotinib ile elde edilen progresyonsuz sağkalım medyan 13,04 ay olarak saptandı. Daha önce bir basamak kemoterapi alan hastalarda ise crizotinib ile PS 16,88 ay olarak bulundu. Tüm grup ele alındığında metastatik olma zamanından itibaren genel sağkalım 37,74 ay olarak saptanmıştır

TARTIŞMA ve SONUÇ: ALK mutasyonu pozitif akciğer kanseri olgularında sağkalım süresi kemoterapi ile karşılaştırıldığında hedefe yönelik tedaviler ile belirgin olarak artmıştır. Bizim çalışmamızda da crizotinib ile tek merkez gerçek yaşam verileri ikinci basamak hariç literatürle uyumludur.

Anahtar Kelimeler: Crizotinib, ALK mutasyonu, Akciğer kanseri

\begin{abstract}
INTRODUCTION: Non- small cell lung cancer (NSCLC) with ALK-mutation is a small group of lung cancer. Especially last years, treatment outcomes of NSCLC with ALK-mutation are increased due to developing many new targeted therapies against ALK mutation. In this study, we aim to detect clinical feature and survival outcomes of patients who had ALK mutation positive and treated with crizotinib in any treatment line.

METHODS: The patients who followed in Ankara Atatürk Chest Disease and Chest Surgery Education and Research Hospital, Department of Medical Oncology between 2014-2018 were enrolled. The data of patients were obtained retrospectively.

RESULTS: Totally, 48 patients were enrolled to study and most of these patients were metastatic (86.7\%) and non-smoker $(68.8 \%)$. Median progression-free survival (PFS) of the patients who treated with crizotinib as firstline and second-line (after one-line chemotherapy) were 13.04 months and 16.88 months, respectively. Overall survival of patients who treated with crizotinib in any treatment-line was 37.74 months.

DISCUSSION AND CONCLUSION: In NSCLC with ALK-mutation, superior outcomes are obtained with crizotinib and the other tyrosine kinase inhibitors that targeted to ALK. In our study, real-life data of crizotinib was found as compatible with the previous trial except for second-line treatment
\end{abstract}

Keywords: Crizotinib, ALK mutation, Lung cancer

\section{GİRIŞ}

Akciğer kanseri tüm dünyada en sik görülen ve en sık kanser ilişskili ölümlere neden olan kanser türlerinden biridir. Amerika Birleşik Devletleri (ABD) verilerine göre 2019 yılında akciğer kanseri her erkeklerde hem de kadınlarda en sık görülecek 2. kanser olarak tahmin edilmektedir. Aynı zamanda akciğer kanserleri hem erkeklerde hem de kadınlarda en sık kanser ilişkili ölüm nedeni olacağ tahmin edilmektedir.(1) Türkiye 2015 kanser istatistiklerine göre ise akciğer kanseri erkeklerde en sik görülen kanser iken kadınlarda ise en sık görülen 4. Kanser olarak 
saptanmıştır. Akciğer kanserleri başlıca iki histopatolojik alt gruba ayrılabilir; küçük hücreli akciğer kanseri ve küçük hücre diş1 akciğer kanseri (KHDAK). En s1k KHDAK alt tipi görülmekle birlikte KHDAK'nin de alt tipleri mevcuttur. Bunlar başlica adenokarsinom, skuamoz hücreli kanser (SCC), büyük hücreli akciğer kanseri ve siniflandirilamayan (NOS) olarak gruplanabilir. $\mathrm{Bu}$ alt tiplerden ise en $\mathrm{sik}$ görülen adenokarsinom görülmekle birlikte tüm KHDAK'li olguların yaklaşık \%40 50'sini oluşturmaktadır.

Akciğer kanseri gelişiminde birçok etken suçlanmaktadır. Sigara en sik akciğer kanseri ile ilişkili neden olarak görülmekle birlikte çeşitli çevresel maruziyetlerde (biomass maruziyeti, radon, asbest vb.) akciğer kanseri oluşumunda suçlanmaktadır. Akciğer kanseri oluşum sürecinde çok önemli bir basamakta sürücü (driver) mutasyon olarak belirtilen genetik değişikliklerdir. $\mathrm{Bu}$ mutasyonlar genelde hücrenin proliferasyonun ve yaşamı için kritik önemi olan sinyal ileti proteinlerinin genlerinde görülür. En sik görülen sürücü mutasyonlar KRAS, EGFR, ALK, ROS-1, HER-2ve BRAF mutasyonlarıdır. $\mathrm{Bu}$ mutasyonların bir diğer önemi ise bu mutasyonlara yönelik hedefe yönelik ajanların geliştirilmiş olması ve bu tedavilerin klasik kemoterapiye göre hem etkinlik hem de yan etkiler olarak anlaml derecede daha üstün olmasıdır. Anaplastik lenfoma kinaz (ALK) mutasyonu tüm adenokanserli olgularının yaklaşık olarak $\% 5$ 'inde pozitif olarak saptanmaktadır.(2) Özellikle genç, kadın, sigara içmeyen ve Asya kökenli hastalarda daha s1k olarak görülmektedir. Bununla birlikte çok nadir de olsa sigara içmeyen SCC olgularında da saptanabilmektedir. Günümüzde tanı ve tedavi k1lavuzlarında tüm adenokanserli hastalar ve sigara içmemiş SCC hastalarında ALK ve diğer sürücü mutasyon analizi yapılması önerilmektedir.

Günümüzde ALK pozitif KHDAK'de birçok hedefe yönelik tedavi seçeneği mevcuttur. Daha önce hiç tedavi almamış hastalarda crizotinib, alectinib, brigatinib ve seritinib; crizotinib tedavisi altında hastalık progresyonu görülen olgularda alectinib, seritinib, brigatinib şu anda kullanımı onay almış tedavi seçenekleridir. Bunların dışında yeni geliştirilen birçok hedefe yönelik tedavi Adress for correspondence: Uzm. Dr. Burak Bilgin, Ankara Atatürk Göğüs Hastalıkları Ve Göğüs Cerrahisi Eğitim Ve Araştırma Hastanesi, Tıbbi Onkoloji Polikliniği, Keçiören Ankara Türkiye

e-mail: drbbilgin@ @otmail.com

Available at www.actaoncologicaturcica.com Copyright $\odot$ Ankara Onkoloji Hastanesi ajanı bulunmaktadır. Crizotinib hem tedavi almamış hem de kemoterapi sonrasında progresyon gösteren hastalarda kemoterapiye karş1 üstünlüğü gösterilmiş olan ilk tirozin kinaz inhibitörüdür.(3, 4) Son bir y1lda kullanıma giren yeni ve daha etkili ajanlar olmakla birlikte tedavi kılavuzlarında halen önerilen bir ajandır.

Biz bu çalışmada KHDAK'nin nadir görülen ALK mutasyonu pozitif alt grubunun klinik özelliklerini belirlemek ve birinci veya daha sonra ki basamaklarda crizotinib tedavinin etkinlik ve yan etkilerinin saptanmasını amaçladık.

\section{MATERYAL ve METOD}

Ankara Atatürk Göğüs Hastalıkları ve Göğüs Cerrahisi Eğitim ve Araştırma Hastanesi, Tıbbi onkoloji polikliniğine 2014 - 2018 y1lları arasında başvurmuş, ALK mutasyonu pozitif ve herhangi bir basamakta crizotinib tedavisi almış olan 18 yaş üzeri hastalar çalışmaya dâhil edilmiștir. Hastalara ait klinik özellikle dosya ve hastanenin elektronik kayıt sisteminden retrospektif olarak toplanmıştır. Hastaların klinik özellikleri olarak yaş, cinsiyet, sigara içme durumu, hastalık evresi, metastaz olan hastalarda metastaz yerleri saptandi. basamağına göre birinci basamak, ikinci basamak ve 3 ve üzeri basamak olarak 3 gruba sınıflandırıldı. Crizotinib tedavisi başlandıktan sonra Yanit değerlendirmesi RECIST (Response Evaluation Criteria in Solid Tumors) kriterlerine (5) ve yan etkiler National Cancer Institute Common Terminology Criteria for Adverse Events (AEs) version 4.0 (6) göre yapıldı. Genel sağkalım (GS), tanıdan hastanın ölümüne veya hastanın klinikte son değerlendirme gününe kadar geçen süre olarak tanımland1 ve hesapland1. Progresyonsuz sağkalım süresi (PS) ise hastalığı olanlarda tedavinin başlangıcından hastalık ilerlemesi ya da ölüme kadar geçen süre (ay) olarak esas alındi.

\section{İstatistik Analiz}

Veriler, SPSS 23.0 yazılım paket program kullanılarak analiz edildi. Nominal değişkenler ve sayısal veriler için Fisher ve Ki-Kare testleri kullanıldı. Sağkalım oranları için Kaplan-
Hastalar crizotinib tedavisi alma 
Meier yöntemi kullanıldı ve karşılaştırmalar log-rank testi ile yapıldı. P $<0,05$ değeri istatistiksel olarak anlamlı kabul edildi.

\section{SONUÇLAR}

Ankara Gögüs Hastalıkları ve Göğüs Cerrahisi E.A.H tıbbı onkoloji polikliniğine 2014- 2018 yılları arasında başvuran toplam 48 ALK mutasyonu pozitif ve herhangi bir basamakta crizotinib tedavisi alan hasta çalışmaya dâhil edildi. Hastaların ortanca yaşı 52 (26-82) olarak saptandı. Hastaların \%56,3'ü erkek, $\% 43,7$ 'si ise kadınd. Tüm hastalar adenokarsinom alt tipindeydi. Tan 1 anında hastaların \%86,7'si metastatik iken \%13,3'ü ise lokal tedavilere uygun olmayan lokal ileri hastalıktı. Hastaların \%68,8'ini hiç sigara içmemiş hastalar oluşturmaktayken, $\% 28,1$ 'i daha önce sigara içmiş fakat bırakmış, \%3,1'i ise halen sigara içen hastalardan oluşmaktaydı. Çalışmaya dâhil edilen hastaların detaylı demografik verileri tablo 1'de verilmiştir.

Tüm hastaları incelendiğinde 21 hastanın $(\% 43,75)$ crizotinib tedavisini birinci basamak tedavi olarak kullandığı, 21 hastanın $(\% 43,75)$ ikinci basamak tedavi olarak kullandığı, 6 hastanın $(\% 12,5) 3$ ve sonra ki tedavi basamaklarında crizotinib tedavisi kullandığı saptanmıştır.

Birinci basamakta crizotinib alan hastalar incelendiğinde; medyan progresyonsuz sağkalım (mPS) 13,04 ay olarak saptandı (Şekil 1). Crizotinib ile yanıt oranı $\% 80$ (tam yanıt oranı $\% 2,9$; parsiyel yanıt oranı: \% 77,1), klinik fayda oranı ise (regresyon ve stabil yanıt sağlanan hasta oran1) ise $\% 91,4$ olarak saptandi. Hastaların \%8,6'sinda ise en iyi yanıt olarak progresyon olduğu veya ilk yanıt değerlendirmesine kadar hastaların exitus olduğu saptandı. Birinci basamak tedavide crizotinib alan hastaların yan etkileri değerlendirildiğinde hastaların \%61,5'sinde herhangi bir derecede yan etki gelişmişti. Grad 3-4 yan etki ise hastaların \%16,7'sinde görüldü. Bununla birlikte yan etki nedeniyle sadece 2 hastada tedavi kesildi. En sik görülen yan etkiler sirasiyla karaciğer fonksiyon testlerinde (KCFT) bozukluğu $(\% 27,1)$, ödem $(\% 6,8)$, myalji $(\% 6,8)$, halsizlik $(\% 5,1)$, görme bozukluğu $(\% 3,4)$, iştahsızlık $(\% 1,7)$ ve bulantıyd1 $(\% 1,7)$. En sık görülen grad 3-4 yan etki ise KCFT yüksekliğiydi $(\% 10,2)$
Daha önce bir basamak kemoterapi alan ve ikinci basamak tedavi olarak crizotinib kullanan 21 hasta incelendiğinde ise mPS 16,8 ay olarak saptandı (Şekil 2). Objektif yanıt oranı ise \%78,76 olarak bulundu. Hastaların \%92,9'unda klinik fayda mevcuttu (objektif yanit + stabil yanit). Hastaların \%7,1'inde ise en iyi yanıt olarak progresyon olduğu veya ilk yanıt değerlendirmesine kadar hastaların exitus olduğu saptand. İkinci basamak crizotinib kullanan hastaların birinci basamak tedaviler incelendiğinde hastaların \%84,2'sine pemetrexed ve platin kombinasyonu uygulandığ1, \%15,8'inin ise taksan ve platin kombinasyonun uygulandığı saptand. Hastalar birinci basamak tedavi olarak medyan 4 kür tedavi almıştı (min-maks; 2-6 kür). Bu hastalar incelendiğinde ikinci basamak crizotinib alan hastaların \%36,8'inin birinci basamak kemoterapi sirasinda veya sonrasinda progresyon görülmeden crizotinib tedavisi başlanan hastalar olduğu saptandı. Üç ve daha sonraki basamaklarda crizotinib kullanan ise 6 hasta vard. $\mathrm{Bu}$ hastalar incelendiğinde ise medyan PS 6,62 ay (\%95 GA: 0,34- 12,4) olarak saptandi.

Sağkalım açısından tüm grup incelendiğinde 48 hastanın 22'sinin exitus olduğu izlendi. Tanı anından itibaren ortanca sağkalım 37,75 ay (\%95 GA: 19,3 - 56,1) olarak bulundu (Şekil 3). Ek olarak; 12, 24 ve 36 aylık sağkalım oranları sırasıyla $\% 85, \% 69$ ve $\% 47,7$ olarak saptand.

\section{TARTIŞMA}

$\mathrm{Bu}$ çalışmaya toplam 48 ALK mutasyonu pozitif hasta dâhil edilmiş olup bu hastaları $\% 43.75$ 'i birinci basamak, \%43,75'i ikinci basamak ve \%12,5'u ise 3 veya sonraki basamaklarda crizotinib tedavisi almıştı. Metastatik hastalarda en sik görüle metastaz bölgesi beyindi. Daha sonra sirasıyla kemik ve plevra metastazları görülmekteydi. Hastaların çoğunluğu sigara içmeyen hastalardan oluşmaktayd. Crizotinib ile sağlanan medyan PS ise birinci basamak hastalarda 13,04 ay, ikinci basamak hastalarda 16,88 ay, 3 veya daha fazla basamak sonrası crizotinib kullanan hastalarda ise 6,62 ay olarak saptandı. Tüm grup ele alındığında genel sağkalım ise medyan 37,74 ay olarak bulundu. 
Tablo-1: Hastaların demografik özellikleri

\begin{tabular}{|l|l|}
\hline Parametre & N \\
\hline Yaş (Ortanca, min-maks) & $52(26-82)$ \\
\hline Cinsiyet & \\
Erkek & $27(\% 56,3)$ \\
Kadın & $21(\% 43,7)$ \\
\hline Sigara & $32(\% 68,8)$ \\
Hiç içmemiş & $14(\% 28,1)$ \\
Bırakmış & $2(\% 3,1)$ \\
İçiyor & 26,5 paket/yıl \\
\hline Sigara (ortanca, paket/yıl) & \\
\hline Hastalık Evresi & $41(\% 86,7)$ \\
Metastatik & $7(\% 13,3)$ \\
Lokal İleri & \\
\hline Beyin metastazı & $\% 37,5$ \\
Var & $\% 62,5$ \\
Yok & \\
\hline Karaciğer metastazı & $\% 12,8$ \\
Var & $\% 87,2$ \\
Yok & \\
\hline Sürrenal Metastaz & $\% 18,8$ \\
Var & $\% 81,2$ \\
Yok & $\% 31,3$ \\
\hline Kemik Metastazı & $\% 68,2$ \\
Var & $\% 27,7$ \\
Yok & $\% 72,3$ \\
\hline Plevra Metastazı & \\
Var & \\
Yok & \\
\hline
\end{tabular}

ALK mutasyonu pozitif hastalarda crizotinib ile standart kemoterapinin karşılaştırıldığı faz 3 PROFILE 1014 çalışmasında daha önce tedavi almamış hastalara birinci basamak olarak crizotinib ve pemetrexed ile birlikte sisplatin/karboplatin uygulanmıştır.(4) Çalışmanın birincil sonlanım noktas1 olan PS crizotinib kolunda 10,90 ay olarak saptanırken kemoterapi kolunda ise 7 ay olarak saptanmıştır. Objektif yanıt oranı ise crizotinib kolunda \%75 olarak saptanmıştır. Bu çalışma sonrası crizotinib tedavisinin kemoterapiye birinci basamakta üstünlügü gösterilmiş olup standart tedavi olarak kabul edilmiştir. Bununla birlikte crizotinib ile elde edilen gerçek yaşam verilerine bakıldığında daha önce tedavi almamış ALK pozitif hastalarda crizotinib ile benzer şekilde 10,40 ay PS sağlanmıştır.(7) Bizim hasta grubumuza baktığımıza ise birinci basamak tedavide crizotinib ile yaklaşık 13,04 ay progresyonsuz sağkalım ve $\% 80$ objektif yanıt oranı elde edildiği görülmektedir. PROFILE 1014 çalışmasının sonuçları ile karşılaştırıldığında bizim hasta grubumuzda PS'da yaklaşık 3 ay ve yanıt oranında ise $\% 5$ oranında daha iyi sonuçlar olduğu görülmektedir. Fakat hem hasta sayısının az olması hem de tek merkez deneyimi nedeniyle arada ki farkın klinik olarak anlamlı olmadığı ve bulguların literatür verileri ile benzer olduğu düşünülebilir.

ALK mutasyonu pozitif hastalarda daha önce bir basamak kemoterapi almış hastalarda crizotinibin etkinliğinin araştırıldığ 1 faz 3 PROFILE 1007 çalışmasında tek ajan dosetaksel veya pemetrexede karşın crizotinibin PS üstünlüğü gösterilmiştir.(3) Crizotinib kolunda PS 7,70 ay olarak saptanırken kemoterapi kolunda ise 3 ay olarak bulunmuştur (Hazard oranı: 0,49; $\mathrm{p}<0,001$ ). Yanıt oranı ise crizotinib kolunda \%65 olarak saptanmıştır. ABD ve Kanada'dan bildirilen crizotinibin ikinci basamak kullanımı ile ilgili gerçek yaşam verilerinde PS 9 ay, yanıt oranı ile $\% 56$ olarak saptanmıştır.(8) Bizim çalışmamızda ise daha önce bir basamak kemoterapi alan hastalarda crizotinib ile progresyonsuz sağkalım 16,80 ay ve yanıt oranı ise \% 78,70 olarak bulundu. Bizim çalışmamızda literatür verileri ile karşılaştırıldığında daha uzun PS ve daha yüksek yanıt oranı saptanması birkaç faktöre bağl1 olabileceğini düşünmekteyiz. Birinci olarak nispeten az hasta sayısı ve tek merkez takipli olması, ikincisi muhtemelen hastaların bir kısmının kemoterapi alırken crizotinib erişimi sağlanması nedeniyle kemoterapi altında veya sonrasinda progresyon gelişmeksizin crizotinibe geçilmesi; son olarak ise bizim çalışmamızda ki hasta özelliklerinin daha iyi olmasıyla ilişkili olabilir. 3 veya daha fazla basamak tedavi alan hastalarda saptanan 6,60 aylık PS ise beklenilen bir bulgudur ve ALK pozitif olan hastalarda crizotinib gibi tirozin kinaz inhibitörleri ile tedaviye erken başlamanın önemini göstermektedir.

Günümüzde ALK pozitif akciğer kanserinde crizotinib dişında birinci basamak ve crizotinib sonrası etkinliği gösterilen birçok ajan vardır. Birinci basamakta alektinib, brigatinib ve ceritinib, crizotinib veya kemoterapiye göre üstünlüğü gösterilmiş diğer ajanlardir.(9-11). Crizotinib altında progresyon gösteren hastalarda ise benzer şekilde alektinib, ceritinib, brigatinib ve lorlatinib kemoterapiye karşı etkinlikleri gösterilmiş ajanlardır.(12-15)

Birinci basamakta crizotnibin araştırıldığı PROFILE 1014 çalışmasının güncellenmiş genel sağkalım verilerinde crizotinib ile medyan sağkalıma ulaşılamamışken kemoterapi ile 47,50 ay 
olarak saptanmıştır.(16) Crizotinib sonrası yeni nesil tirozin kinaz inhibitörleri ile sıralı tedavinin genel sağkalım üzerine etkilerinin araştırıldı çalışmasında ise metastatik hastalık gelişiminden itibaren genel sağkalım 89,60 ay olarak saptanmıştır. Tek crizotinib alan hastalarda ise genel sağkalım 16,60 ay olarak bulunmuştur.(17) Bizim çalışmamızda ise crizotinib ile kullanılan basamaktan bağımsız olarak metastatik hastalık gelişiminden itibaren 37,7 aylık genel sağkalım saptanmıştır. Hastaların çoğunun crizotinib sonrası yeni nesil tirozin kinaz inhibitörlerine ulaşamaması genel sağkalım süresinin literatürde belirtilen sürelerden kısa olmasının en önemli sebebidir. Bizim çalışmamızın en önemli kısıtlılıkları retrospektif olarak gerçekleştirilmiş olması, tek merkez deneyimi olmas1 ve nispeten az hasta sayıs1 ile gerçekleştirilmiş olmasıdır. Bununla birlikte akciğer kanserinin nadir görülen bu alt grubunda Türkiye gerçek yaşam verilerini sağlamış olması nedeniyle önem göstermektedir.

\section{REFERANSLAR}

1. Siegel RL, Miller KD, Jemal A. Cancer statistics, 2019. CA Cancer J Clin. 2019;69(1):7-34.

2. Pikor LA, Ramnarine VR, Lam S, Lam WL. Genetic alterations defining NSCLC subtypes and their therapeutic implications. Lung Cancer. 2013;82(2):179-89.

3. Shaw AT, Kim DW, Nakagawa K et al. Crizotinib versus chemotherapy in advanced ALK-positive lung cancer. N Engl J Med. 2013;368(25):2385-94.

4. Solomon BJ, Mok T, Kim DW et al. First-line crizotinib versus chemotherapy in ALK-positive lung cancer. N Engl J Med. 2014;371(23):2167-77.

5. Therasse P, Arbuck SG, Eisenhauer EA et al. New guidelines to evaluate the response to treatment in solid tumors. European Organization for Research and Treatment of Cancer, National Cancer Institute of the United States, National Cancer Institute of Canada. J Natl Cancer Inst. 2000;92(3):205-16.

6. Common Terminology Criteria for Adverse Events (CTCAE) Version 4.0. May 28, U.S Department of Health and Human Services; National Institutes of Health; National Cancer Institute. Available from
URL:

http://evs.nci.nih.gov/ftp1/.CTCAE/CTCAE_4.03_ 2010-06-14. (Date of Access:25 Dec, 2015).

7. Reynolds C, Masters ET, Black-Shinn J et al. RealWorld Use and Outcomes of ALK-Positive Crizotinib-Treated Metastatic NSCLC in US Community Oncology Practices: A Retrospective Observational Study. J Clin Med. 2018;7(6).

8. Davis KL, Kaye JA, Masters ET, Iyer S. Realworld outcomes in patients with ALK-positive nonsmall cell lung cancer treated with crizotinib. Curr Oncol. 2018;25(1):e40-e9.

9. Peters S, Camidge DR, Shaw AT et al. Alectinib versus Crizotinib in Untreated ALK-Positive NonSmall-Cell Lung Cancer. N Engl J Med. 2017;377(9):829-38.

10. Camidge DR, Kim HR, Ahn MJ et al. Brigatinib versus Crizotinib in ALK-Positive Non-Small-Cell Lung Cancer. N Engl J Med. 2018;379(21):202739.

11. Soria JC, Tan DSW, Chiari R et al. First-line ceritinib versus platinum-based chemotherapy in advanced ALK-rearranged non-small-cell lung cancer (ASCEND-4): a randomised, open-label, phase 3 study. Lancet. 2017;389(10072):917-29.

12. Novello S, Mazieres J, Oh IJ et al. Alectinib versus chemotherapy in crizotinib-pretreated anaplastic lymphoma kinase (ALK)-positive non-small-cell lung cancer: results from the phase III ALUR study. Ann Oncol. 2018;29(6):1409-16.

13. Shaw AT, Kim TM, Crino $L$ et al. Ceritinib versus chemotherapy in patients with ALK-rearranged non-small-cell lung cancer previously given chemotherapy and crizotinib (ASCEND-5): a randomised, controlled, open-label, phase 3 trial. Lancet Oncol. 2017;18(7):874-86.

14. Kim DW, Tiseo M, Ahn MJ et al. Brigatinib in Patients With Crizotinib-Refractory Anaplastic Lymphoma Kinase-Positive Non-Small-Cell Lung Cancer: A Randomized, Multicenter Phase II Trial. J Clin Oncol. 2017;35(22):2490-8.

15. Solomon BJ, Besse B, Bauer TM et al. Lorlatinib in patients with ALK-positive non-small-cell lung cancer: results from a global phase 2 study. Lancet Oncol. 2018;1912):1654-67.

16. Solomon BJ, Kim DW, Wu YL et al. Final Overall Survival Analysis From a Study Comparing FirstLine Crizotinib Versus Chemotherapy in ALKMutation-Positive Non-Small-Cell Lung Cancer. J Clin Oncol. 2018;36(22):2251-8.

17. Duruisseaux M, Besse B, Cadranel J et al. Overall survival with crizotinib and next-generation ALK inhibitors in ALK-positive non-small-cell lung cancer (IFCT-1302 CLINALK): a French nationwide cohort retrospective study. Oncotarget. 2017;8(13):21903-17. 